\title{
Job SECURITY AND WORK ABSENCE: EVIDENCE FROM A NATURAL EXPERIMENT
}

\author{
ASSAR LINDBECK \\ MÅRTEN PALME \\ MATS PERSSON
}

CESIFO WORKING PAPER No. 1687

CATEGORY 1: PUBlic FinANCE

MARCH 2006

An electronic version of the paper may be downloaded

- from the SSRN website:

www.SSRN.com

- from the CESifo website:

www.CESifo-group.de 


\title{
JOB SECURITY AND WORK ABSENCE: EVIDENCE FROM A NATURAL EXPERIMENT
}

\begin{abstract}
We analyze the consequences for sickness absence of a selective softening of job security legislation for small firms in Sweden in 2001. According to our differences-in-difference estimates, aggregate absence in these firms fell by $0.2-0.3$ days per year. This aggregate net figure hides important effects on different groups of employees. Workers remaining in the reform firms after the reform reduced their absence by about one day. People with a high absence record tended to leave reform firms, but these firms also became less reluctant to hire people with a record of high absence.
\end{abstract}

JEL Code: H53, I38, J22, J5, M51.

Keywords: seniority rules, sick pay insurance, firing costs, moral hazard.

Assar Lindbeck
The Research Institute of Industrial
Economics
P.O. Box 55665
10215 Stockholm
Sweden
Assar.Lindbeck@iies.su.se

Mats Persson

Institute for International Economic Studies

Stockholm University

10691 Stockholm

Sweden

Mats.Persson@iies.su.se

We are grateful for comments from Laura Larsson, Per Pettersson Lidbom and Peter Skogman Thoursie on an earlier draft of this paper as well as for comments given on seminars at the Trade Union Institute for Economic Research in Stockholm, IFAU in Uppsala, Helsinki University, The Research Institute of Industrial Economics in Stockholm, the Institute for Social Research at Stockholm University and Department of Economics at Uppsala University. We are also grateful to David von Below for excellent research assistance. Mårten Palme acknowledges financial support from The Swedish Council for Working Life and Social Research (FAS). The Swedish Social Insurance Agency generously provided data. The authors take full responsibility for any remaining errors and shortcomings. 


\section{Introduction}

In several developed countries, welfare arrangements provide economic security not only through compulsory income insurance but also via job-security legislation. Indeed, the latter functions as a de facto income insurance via the employment contract, in particular for workers with seniority rights. Like other types of insurance, job security legislation is, however, vulnerable to moral hazard, which in this case may take the form of shirking at work or irregular work attendance, since the risk of being fired for such behavior is reduced by the legislation.

It is increasingly understood that the effects of various systems of income and job security may interact when it comes to, e. g., the consequences for the functioning of the labor market. This interaction takes place through several different channels. For instance, the risk of losing one's job by often calling in sick falls with strict jobsecurity legislation, which is likely to increase sickness absence. Moreover, people with a high propensity to call sick will have an incentive to acquire "seniority capital" by hanging on to a job even if there is a "bad match". The behavior of firms is also influenced by job security legislation; with high security, firms are induced to avoid employing individuals with potential health problems.

The effects of job security legislation on absence behavior are difficult to analyze empirically. In a job-security regime that is uniform across the nation, we would not obtain any variation in the rules necessary for econometric analysis. If, on the other hand, the job security rules differ between firms (or across industries), we would get self-selection problems: individuals with a high propensity to be absent may selfselect into specific jobs with high job security. Thus, it is essential to have access to some form of exogenous variation in the job security experienced by the workers.

The previous empirical literature on work absence behavior contains two branches of particular relevance for the issue described above. The first consists of studies on the relation between work absence and unemployment. The idea behind these studies is that unemployment functions as a disciplining device: high unemployment makes 
shirking and absence more costly for the worker. Several papers have thus indicated that absence tends to fall in recessions, when workers feel less safe in having a job. ${ }^{1}$ The second branch consists of empirical studies of the relation between the employment contract and absence behavior. For instance, Ichino and Riphahn (2004) have compared work absence among German government officials with different degrees of tenure, and they found tenure to be associated with relatively high work absence. In a subsequent study, using individual data for studying work absence in a large Italian bank, the same authors found that absence increased among newly employed when the probation period was over and hence, job security became stronger (Ichino and Riphahn, 2005).

In this study, we follow another track by exploring a Swedish reform of job security legislation, implemented on January 1, 2001. The reform allowed employers with up to ten employees to exempt two of their employees from the seniority rules of the Swedish job security legislation. Since this change in job security legislation only applied to a particular group in the labor market - employers and employees in firms with up to ten employees - the policy change generated one treatment group and one control group. The reform can therefore be interpreted as a natural experiment, which makes it possible to address a number of issues that have not been adequately dealt with so far. First, it allows an explicit analysis of a public policy intervention, which directly affected employment security. Therefore, our results have immediate policy relevance. Second, since we have access to individual panel data, it is possible to distinguish between a "compositional effect" and a "behavioral effect". More specifically, we can investigate whether a given change in sickness absence in the treatment group is mainly due to workers becoming more reluctant to calling in sick (a behavioral effect), or is rather due to changes in the composition of the workforce in the treatment group (a compositional effect).

The empirical analysis consists of three main parts. We first study the overall effect of the reform on work absence behavior (behavioral + compositional effects) using a conventional differences-in-difference methodology. In this context, we also exploit the fact that the reform had a differential effect through the number of employees

\footnotetext{
${ }^{1}$ For aggregate time-series studies, see Henrekson and Persson (2002) and Osborg Ose and Dyrstad
} 
within the group affected by the reform, since the two employees that could be exempt from the seniority rules constitute a different share of the workforce. Second, we allow for the possibility that the workforce of firms in the treatment group may be endogenous with respect to the reform; individuals with a high propensity to call sick may have left firms in the treatment group as a result of the weaker job security in such firms. We account for this possibility by using an instrumental-variable (IV) approach. As an instrument, we assign the individual to the firm where he worked in 1999 , before it was at all possible to know about the changes in the job security legislation. By this approach, we are able to distinguish between effects on the absence behavior of workers on a specific job, and effects on those who change job. Finally, we study the effect of the compositional change directly by constructing twoyear panels. By studying such panels, we can compare work absence behavior of workers entering and quitting firms affected by the policy change before and after the reform, respectively.

We find an overall reduction in the average work absence rate of about 0.2-0.3 days. This is, however, an aggregate figure. For individuals who continue to work in a treatment-group firm, the fall in absence is about one day. We also find that persons with high absence tend to leave the firms affected by the reform. This is consistent with the predictions of lower hiring costs and a reduction in the value of the "seniority capital" as a result of the change in job security legislation. Finally, we find that firms became less reluctant to hire workers with a history of high sickness absence, presumably because the reform reduced the hiring and firing costs for firms.

The paper is organized as follows. Section 2 gives an overview of how the reform changed the incentives for employers and employees, respectively. In section 3, we describe Sweden's job security legislation and sick-pay insurance system. Section 4 gives theoretical predictions of how firms within the treatment group, with different numbers of employees, will be affected by the reform. The data are presented in Section 5 and the basic econometric specification in Section 6. Section 7 presents the results. The first sub-section presents the estimates of the overall effect of the reform, i.e., the combined effect of behavioral and compositional changes. The second and 
third sub-sections present some tests of the timing of the effects, and the consequences for firms of different sizes within the treatment group. The fourth subsection deals with detecting and accounting for possible endogeneity problems in the analysis. The fifth sub-section takes a closer look at endogenous compositional changes. Finally, Section 8 concludes.

\section{The Different Effects of Changes in the Employment Security Legislation}

As compared to spot labor markets, employment contracts re-allocate income risk from worker to employers (see e.g. Malcomson, 1999). Job security legislation accentuates this shift of income risk. Such a shift, however, creates a moral-hazard problem, since the cost for workers of shirking goes down. Employers' behavior may also change, since the employment security legislation makes it more costly to hire the wrong person.

A relaxation of the job security legislation, like the Swedish 2001 reform, shifts risk in the opposite direction. The effects of such a change can be categorized as follows:

(i) Compositional effects. Weaker job security may change the employment status for some workers, with consequences for the composition of the labor force in individual firms. We distinguish between the following three channels for such compositional effects:

a) Firing. Since less rigorous employment protection makes it easier for employers to get rid of workers with high work absence, the remaining labor force will consist of individuals with a relatively low propensity to be absent from work.

b) Hiring. In principle, less rigorous employment protection reduces firing costs, hence making employers less choosy in their hiring decisions. They will therefore pay less attention to screening. As a result, more people with potential health problems will be hired, which tends to increase absence.

c) Quits. When employment protection becomes softer and hence, the previously acquired "seniority capital" falls for some 
individuals, they may be more inclined to quit in the case of a bad match. The number of bad matches in the labor market will then fall, and the absence rate tends to go down - assuming that absence is a way for workers of coping with a bad match. ${ }^{2}$

(ii) Behavioral effects among stayers. Less rigorous employment protection makes it more costly for a worker to be absent, since workers with high absence are now more likely to be fired. Employees ("stayers") may therefore become less inclined to be absent from work.

The first two effects - compositional effects $a$ and $b$ - refer to employer behavior. In the case of a softening of the job security legislation, these effects work in different directions and will lead to a theoretically ambiguous effect on the composition of the work force. The two other effects - compositional effect $c$ and the behavioral effect refer to employee behavior, and they both tend to reduce sickness absence.

To sum up, while the behavioral effects on stayers are likely to be unambiguous (softer job security legislation leading to less absence), the compositional effects are ambiguous since the hiring effect works in the opposite direction of the other compositional effects. A given change in total absence is, of course, a combination of all these effects.

\section{The 2001 Swedish Job Security Reform}

Before the 2001 reform, the employer had to obey a seniority rule in the form of "lastin-first-out" in case of redundancy. ${ }^{3}$ The reform softened the rule for small firms in the sense that firms with ten employees or less were allowed to keep two persons regardless of their seniority. Hence, seniority rights were weakened for part of the workforce in such firms.

\footnotetext{
${ }^{2}$ This point has been informally discussed by Rothstein and Boräng (2005), who argue that workers with seniority capital may choose sickness absence rather than quitting in the case of a bad job match.
} 
It is easy to understand that this type of reform had the predicted behavioral and compositional effects discussed in the previous section. In the case of hiring, the reasons are somewhat more involved than in the other cases. The incentive falls for a firm to screen workers in the hiring decision. If the worker turns out to be a good match, it is easier for the firm to keep him in a case of redundancy, and to fire somebody else instead; if instead the match turned out to be bad, it is as easy (or difficult) to fire him as earlier.

The reform was implemented on January 1, 2001, and it is reasonable to assume that it was not expected by employers or employees until 2000, when it was openly discussed. The reason why it could not reasonably have been anticipated before is that it was the result of an unlikely cooperation between the Environmentalist Party and the non-socialist opposition parties in the Parliament. During the first half of 2000, it gradually became more likely that this cooperation could be sustained and result in a job-security reform (cf Table 1 for the chronology of the reform).

We would expect that at least some of these effects materialized already during 2000. In anticipation of the reform, some workers may have reduced their absence, and some firms may have become willing to take greater risks when hiring. For obvious reasons, the effects on firing could not have occurred until 2001.

\footnotetext{
${ }^{3}$ The strictness of the legislation was modified by the possibility that firms and unions could make
} 
Table 1: The chronology of the Parliament's decision to soften the job protection legislation for small firms in Sweden 2001.

\begin{tabular}{|c|c|c|}
\hline Action & Date & Reference \\
\hline $\begin{array}{l}\text { The Environmentalist Party and the Non- } \\
\text { Socialist opposition parties united in requiring } \\
\text { the Government to propose softer job-security } \\
\text { legislation for small firms. The Social } \\
\text { Democratic minority government was } \\
\text { decidedly against such a reform. }\end{array}$ & $\begin{array}{l}\text { April 28, } \\
1999\end{array}$ & $\begin{array}{l}\text { 1998/99:AU9, } \\
\text { rskr } \\
\text { 1998/99:179. }\end{array}$ \\
\hline $\begin{array}{l}\text { As a response to the Parliament's request, the } \\
\text { Ministry of Industry presents a report } \\
\text { containing two alternative technical solutions: } \\
\text { 1.) All firms can exempt two persons from } \\
\text { the last-in-first-out rules. } \\
\text { 2.) Only firms with less than ten } \\
\text { employees can exempt two persons. }\end{array}$ & $\begin{array}{l}\text { February } \\
2000\end{array}$ & Ds 2000:6 \\
\hline $\begin{array}{l}\text { In an attempt to drive a wedge between the } \\
\text { parties advocating labor market reform, the } \\
\text { Government chooses alternative } 1 \text {, and } \\
\text { presents it to the Parliament in the form of a } \\
\text { legislation proposal. But since the } \\
\text { Environmentalist Party only accepted } \\
\text { alternative } 2 \text {, it was clear that this was the only } \\
\text { alternative that would get a majority in } \\
\text { Parliament. }\end{array}$ & May 25, 2000 & $\begin{array}{l}\text { Prop. } \\
\text { 1999/2000:144 }\end{array}$ \\
\hline $\begin{array}{l}\text { The Parliament's Labor Market Committee } \\
\text { votes for alternative } 2 \text {, but modifies it to "ten } \\
\text { employees or less", and presents it to the } \\
\text { Parliament. }\end{array}$ & $\begin{array}{l}\text { September 21, } \\
2000\end{array}$ & 2000/01:AU4 \\
\hline $\begin{array}{l}\text { The Parliament votes for the Labor Market } \\
\text { Committee's proposal. }\end{array}$ & $\begin{array}{l}\text { October 11, } \\
2000\end{array}$ & $\begin{array}{l}\text { Parliament } \\
\text { protocol } \\
2000 / 01: 9\end{array}$ \\
\hline The law is implemented. & $\begin{array}{l}\text { January 1, } \\
2001\end{array}$ & \\
\hline
\end{tabular}

\section{Predicted Effects within the Treatment Group}

Due to the particular design of the reform, we can expect different effects not only between the treatment group and the control group, but also within the treatment group. The right of a firm in the treatment group to exempt two persons from the 
seniority rules clearly has different effects depending on the number of employees. Indeed, it is possible to construct a measure of how large a fraction of the workforce within an individual firm is protected by the seniority rules - and how this fraction changed by the reform.

Assume that, as a result of redundancy, a firm wants to fire exactly one employee. If the firm only had one employee, nobody was protected by the seniority rule before the reform. For a firm with two employees, one person (that is, 50 percent of the workforce) was protected. With three employees, two persons (67 percent) were protected, et cetera. With 10 employees, 9 (i.e., 90 percent) were protected. These calculations are presented in the first three columns in Table 2.

Table 2: Employment protection in small firms before and after the 2001 reform.

\begin{tabular}{|c|c|c|c|c|c|}
\hline \multirow{3}{*}{$\begin{array}{l}\text { Number of } \\
\text { Employees }\end{array}$} & \multicolumn{5}{|c|}{ Protected workers } \\
\hline & \multicolumn{2}{|c|}{ Before reform } & \multicolumn{2}{|c|}{ After reform } & \multirow{2}{*}{$\begin{array}{l}\text { Change in } \\
\text { percentage } \\
\text { of protected } \\
\text { workers }\end{array}$} \\
\hline & Number & Percent & Number & Percent & \\
\hline 1 & 0 & 0 & 0 & 0 & 0 \\
\hline 2 & 1 & 50 & 0 & 0 & -50 \\
\hline 3 & 2 & 67 & 0 & 0 & -67 \\
\hline 4 & 3 & 75 & 1 & 25 & -50 \\
\hline 5 & 4 & 80 & 2 & 40 & -40 \\
\hline 6 & 5 & 83 & 3 & 50 & -33 \\
\hline 7 & 6 & 86 & 4 & 57 & -29 \\
\hline 8 & 7 & 87.5 & 5 & 62.5 & -25 \\
\hline 9 & 8 & 89 & 6 & 67 & -22 \\
\hline 10 & 9 & 90 & 7 & 70 & -20 \\
\hline
\end{tabular}


Columns 4-6 illustrate the situation after the reform. In a firm with only one employee, nobody is protected - just like before. This means, in fact, that the treatment group in the experiment consists of firms with 2-10 rather than 1-10 employees. With two employees, the situation has changed: since the firm can exempt two persons from the seniority rules, nobody is now protected. Indeed, the same holds for a firm with three employees. The reason is that since the firm can exempt any two persons, any of the three employees could be fired in case of a redundancy; thus, no one is protected. With four employees, the person with the highest seniority can feel safe on his job when one person is going to be fired; thus 25 percent of the workforce is protected after the reform. As seen from the table, the fraction increases to 70 percent for a firm with ten employees.

The last column states the change, in percentage points, of the fraction of the labor force protected by the seniority rules. While there is no change for a firm with one employee, the change is -50 percentage points for a firm with two employees, and -67 percentage points for a firm with three employees. For firms with more employees, the change gradually falls (in absolute terms) to -20 percent for a firm with 10 employees. For larger firms, there is, of course, no change at all (as for firms with only one employee), since they were not affected by the reform. This pattern of the change in job security shown in the last column of Table 2 is depicted in Figure 1. Hence, we can make quite specific predictions about the implications for sickness absence not only for the treatment group as compared to the control group, but also for firms of different sizes within the treatment group. 
Figure 1. The 2001 change in employment protection in small firms.

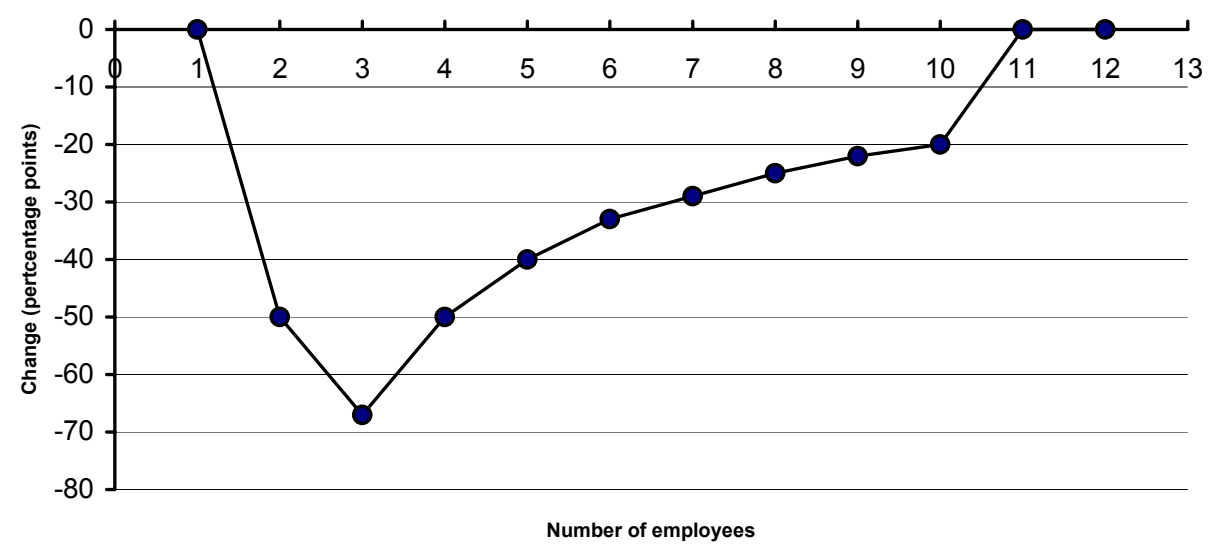

The analysis underlying Figure 1 was performed under the assumption that the firm had to fire exactly one person. The general "U shape" of the curve in the figure, however, carries over to other cases, such as when the firm considers firing two persons, or a certain fraction of the work force. ${ }^{4}$

\section{Data and Measurement}

\subsection{General Description of the Data}

We use the panel data set LISA, containing information on all individuals permanently living in Sweden. LISA consists of data from three main registers:

- The income and wealth register (Inkomst- och förmögenhetsstatistiken, IoF). This register consists of tax return data on all people registered as taxpayers in

\footnotetext{
${ }^{4}$ It should be noted that the numbers in Table 2 only give the fraction of the workforce automatically protected by the legislation. The numbers do not give any information about whether job protection has increased or decreased for specific workers. For instance, a newly employed worker with particularly useful skills, who would have been the first to be fired under the old legislation, might actually have experienced an increased job protection because of the reform. In such a case, somebody else would have been fired instead. It is important to realize, however, that both these persons will have stronger incentives not to shirk than before. Indeed, the last hired person could not influence his probability of being fired in case of redundancy before the reform - while after the reform, he can exert such influence by his absence behavior. Thus, the general predictions in Table 2 and Figure 1 carry over to the case of heterogeneous workers in terms of skills.
} 
Sweden. LISA contains data from this register for each year between 1992 and 2002.

- The Enterprise and Workplace register compiled by Statistics Sweden. This register contains information on employer and workplace for all individuals permanently living in Sweden.

- The National Insurance Board registers. These contain all transactions from the Swedish social insurance system, including the number of days of absence compensated by the compulsory sickness insurance.

There are several reasons why LISA is an excellent data set for the purposes of this study. First, it is a matched employer-employee data set. This means that we have information on key variables on the employer, such as e.g. number of employees and sector, as well as individual information on employees, such as work absence and educational attainments. Second, it contains information on all individuals permanently living in Sweden. This means that we are able to get very large sample sizes also for the quite specific group of workers in the private sector working in firms withten employees or less. It also allows us to get information on the composition of the work force within each workplace.

A third advantage of LISA is that it contains information on all transactions from the administration of compulsory social security in Sweden. This means that we are able to get a very accurate measure of the usage of the sick-pay (temporary disability) insurance program. However, as a measure of work absence, this source of information has the limitation that it does not measure sick leave compensation paid by the employers. During most of the period we study, sick leave compensation for spells up to two weeks was financed by the employer, ${ }^{5}$ which means that we are only able to study sick spells longer than two weeks. This limitation implies that our results should be interpreted as "lower bounds" of the full effect of softer job security legislation on the number of sick days.

5 During the first quarter of 1998, employers paid for sick spells shorter than four weeks. 
We use data for employees in the private sector, employed in establishments with at most 25 employees, aged 25-64 years, over the period 1998-2002 (which is a period during which no major changes in the sick pay insurance system took place). This sample selection resulted in samples of roughly 600,000 persons per year. The reason for excluding larger firms is that we want the control group to be as similar to the treatment group as possible. Thanks to our large data set, such an exclusion still allows us to have a very large sample.

\subsection{Problems of Data Interpretation}

As pointed out earlier, the data we use only cover sick days paid by the government insurance system. The first two weeks of a sick spell are paid by the individual's employer, and those days are not recorded in the data. If moral hazard were more important for short spells than for spell longer than two weeks, our study would underestimate the effects of the job security reform on sickness absence.

Another problem is that the rules of the sickness insurance system were somewhat different in the first quarter of 1998 as compared to the rest of the period. In that quarter, the employer paid for the first four rather than the first two weeks of a sick spell. This feature of the data would create a problem for our analysis if the proportion of sick spells for the control group and the treatment group differed when looking at the first two weeks as compared to the first four weeks. This problem is, however, of limited importance since it only affects one quarter out of eight during the pre-reform period. Limiting the pre-reform period to 1999 only would completely remove the underreporting problem but would, at the same time, reduce the pre-reform period to one year only. We have tried both alternatives and found that the parameter estimates do not differ to any considerable extent for these variations (cf. Section 7.1).

A third type of data problem may be that the size distribution of firms is endogenous to the reform. As we concluded in Section 2, the reform basically implied more discretionary power to small firms in their firing decisions. The number of small firms (up to ten employees) may therefore be expected to increase. This could occur either because larger firms decide to reorganize or split in order to belong to the favored size group, or because small firms would now be more competitive, resulting in larger entry and smaller exit. Both these effects would contaminate the experimental design, 
since they would change the composition of firms across size groups as a result of the experiment.

To highlight this issue, we have computed the percentage changes in the number of firms of different sizes of the workforce between 1999 and 2002. These numbers are shown in Figure 2, which does not suggest that there have been any adjustments to the structure of firms. For instance, the number of firms in the size classes most influenced by the reform (i.e., firms with 2-5 employees) has hardly changed at all. The number of larger firms in the treatment group has indeed increased, but not more than the number of firms in the control group (1 and 11-20 employees).

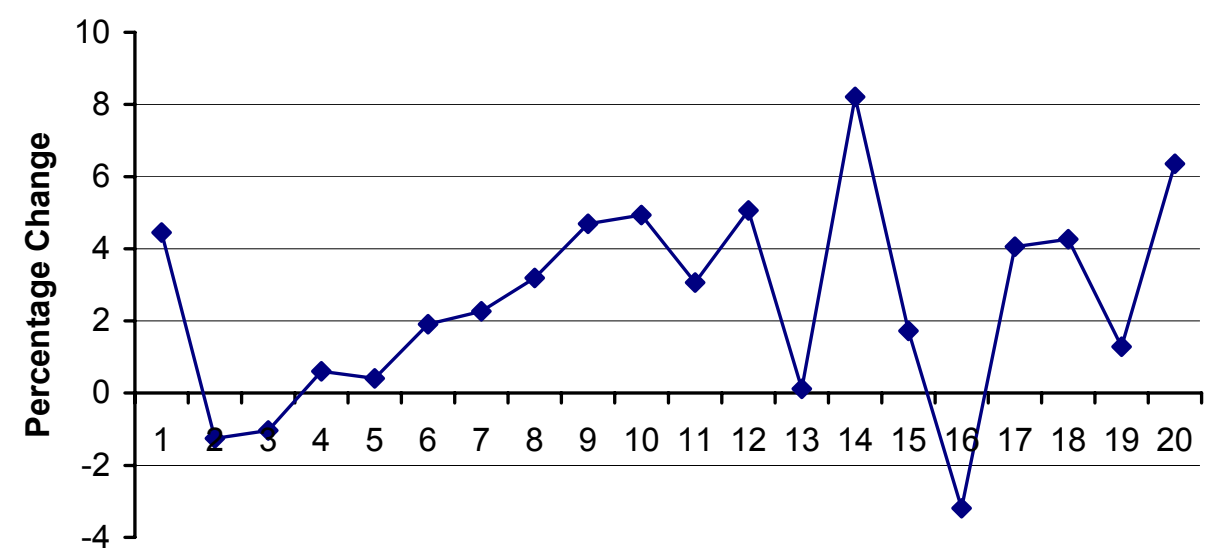

Number of Employees

Figure 2: Percentage change between 1999 and 2002 in number of firms by number of employees.

\subsection{Some Descriptive Statistics}

Table 3 shows some brief descriptive statistics for each of the years used in the study. The experimental group - employees working at establishments with between 2 and 10 employees - corresponds to around 55 percent of the sample. The descriptive statistics also shows that about two thirds of the employees in the group establishments included in the sample are males. 
Table 3: Descriptive statistics.

\begin{tabular}{llllll}
\hline \hline & 1998 & 1999 & 2000 & 2001 & 2002 \\
\hline $\begin{array}{l}\text { Number of } \\
\text { observations }\end{array}$ & 617,694 & 639,099 & 655,477 & 659,783 & 657,911 \\
$\begin{array}{l}\text { Share females } \\
\text { Average age }\end{array}$ & 32.9 & 32.9 & 32.8 & 32.8 & 32.5 \\
$\begin{array}{l}\text { Share in treatment } \\
\text { group, \% }\end{array}$ & 55.1 & 42.3 & 42.5 & 42.8 & 43.0 \\
$\begin{array}{l}\text { Average number of } \\
\text { days absent }\end{array}$ & & 55.1 & 55.0 & 54.8 & 54.4 \\
$\quad \begin{array}{l}\text { Treatment group } \\
\quad \text { Control group }\end{array}$ & 6.36 & 7.51 & 8.85 & 9.87 & 13.48 \\
$\begin{array}{l}\text { Difference between } \\
\text { treatment and control } \\
\text { groups in average }\end{array}$ & -0.04 & -0.01 & -0.27 & -0.26 & -0.17 \\
number of days absent & & & & & \\
$\begin{array}{l}\text { Differences-in- } \\
\text { differences (relative to } \\
\text { previous year) }\end{array}$ & & 0.03 & -0.26 & 0.01 & 0.09 \\
\hline
\end{tabular}

The bottom rows of the table show the development of the average number of days paid for by the public sick-pay insurance in the treatment and control group, respectively. ${ }^{6}$ We see that there was hardly any difference between the two groups in the pre-reform years 1998-1999. However, there is a marked difference from 2000 and onwards, when the reform may have had an effect. The average numbers of sick days of the entire population could be regarded as a stochastic process, with random fluctuations over time. This allows us to make a very preliminary analysis of the effect of the reform on work absence behavior. Following Donald and Lang (2004, p 15), we first regress the differences in the seventh row in Table 3 on a dummy variable taking the value of one for the years after 2000. This procedure assumes the disturbance to be i.i.d. normal. The results suggest a highly significant ( $p$-value 0.016) reduction in the work absence rate of 0.21 days. However, since we only have five observations, the precision of the estimate is quite low and a 95 percent confidence interval ranges from 0.07 to 0.34 .

\footnotetext{
${ }^{6}$ The number of absence days reported in Table 3 may seem surprisingly low. One reason is that we only look at small, private firms (up to 25 employees), where absence is lower than in large private firms and in the public sector. The other reason is that the data only cover sick spells longer than two weeks.
} 
An alternative strategy, also suggested by Donald and Lang (2004), is to make the weaker assumption that the differences-in-differences are i.i.d. normal (i.e., allowing for the possibility that the differences are a correlated random walk) and analyze the one-year differences-in-differences presented in the bottom row of Table 3. Regressing these differences-in-differences on a dummy variable for 1999-2000, once more suggests a highly significant ( $p$-value 0.024 ) reduction in the work absence rate. The point estimate is now 0.30 with a 95 percent confidence interval ranging from 0.10 to 0.51 .

These descriptive data suggest that the reform may, in fact, have reduced the number of sick days, and that the effect was visible already in 2000. Note, however, that these calculations were made in a "one-variable regression", hence without using any control variables such as gender, age, etc. A potential problem with such a simple approach is that the treatment firms and the control firms have different socioeconomic composition, and that trends in absence behavior may differ across socioeconomic groups. Indeed, as we see from Table 4, there are such differences in the case of gender, age and education. Although these differences are not very large, they may create a bias in the estimates of a reform effect. We will therefore control for a number of socio-economic variables by including a battery of such variables, and their interactions with the time variables, in the econometric model specification (see Section 6).

Table 4: Comparison of the control and treatment groups before and after the 2001 reform.

\begin{tabular}{lllll}
\hline \hline & $\begin{array}{l}1999 \\
\text { Control group }\end{array}$ & Treatment group & $\begin{array}{l}2002 \\
\text { Control group }\end{array}$ & Treatment group \\
\hline $\begin{array}{l}\text { No. of } \\
\text { observations }\end{array}$ & & & & \\
\hline $\begin{array}{l}\text { Share females } \\
\text { Average age }\end{array}$ & 31.89 & 33.75 & 31.59 & 33.31 \\
Share education & 42.1 & 42.4 & 42.8 & 43.2 \\
group & & & & \\
1 & 26.38 & 24.69 & 22.25 & 20.33 \\
2 & 37.31 & 36.22 & 38.32 & 39.96 \\
3 & 28.11 & 29.09 & 23.94 & 24.68 \\
4 & 8.19 & 10.01 & 15.46 & 18.03 \\
\hline
\end{tabular}




\section{The Econometric Model}

\subsection{A Differences-in-Differences Specification}

The raw data of Table 3 suggest that the job security reform in 2001 had an effect on work absence, and that this effect materialized already in 2000 . However, the sudden increase in 2000 in the difference between the control group and the treatment group could be the result of other influences than the reform. To investigate this issue, we make an explicit differences-in-difference analysis using a number of control variables (see e.g. Angrist and Krueger, 1999, for an overview of the general methodology). In its simplest form, this approach only relies on the difference between the average number of days of absence in the treated group (those affected by the reform) and the corresponding average for those in the control group (those not affected) before and after the reform, i.e.,

$$
\beta \equiv\left(\bar{S}_{\text {contr,pre }}-\bar{S}_{\text {treat }, \text { pre }}\right)-\left(\bar{S}_{\text {contr,post }}-\bar{S}_{\text {treat }, \text { post }}\right) .
$$

As pointed out in Section 5.1, we will add a number of control variables, and interactions among some of these. To this end, we use a very flexible form for our regression equation:

$$
\begin{aligned}
S_{i t}= & \alpha+\beta \cdot R_{i t}+\gamma_{Y E A R}^{\prime} \cdot Y E A R_{t}+\gamma_{\text {TREAT }}^{\prime} \cdot T R E A T_{i t}+\gamma_{X}^{\prime} \cdot X_{i t}+ \\
& +\gamma_{\text {interact }}^{\prime} \cdot X_{i t} \cdot Y E A R_{t}+e_{i t} .
\end{aligned}
$$

where $S_{i t}$ is the number of sick days of individual $i$ in year $t$. The variable YEAR is a vector of four time dummies, defined by

$$
Y_{t}^{99}=\left\{\begin{array}{l}
1 \text { if } t=1999 \\
0 \text { otherwise }
\end{array}, Y_{t}^{00}=\left\{\begin{array}{l}
1 \text { if } t=2000 \\
0 \text { otherwise }
\end{array}, Y_{t}^{01}=\left\{\begin{array}{l}
1 \text { if } t=2001 \\
0 \text { otherwise }
\end{array}, Y_{t}^{02}=\left\{\begin{array}{l}
1 \text { if } t=2002 \\
0 \text { otherwise }
\end{array} .\right.\right.\right.\right.
$$

Further, TREAT is a dummy variable for being assigned to the treated group, defined by 


$$
\operatorname{TREAT}_{i t}= \begin{cases}1 & \text { if individual } i \text { works in a treatment group firm } \\ & \text { (i.e., a firm with } 2-10 \text { employees }) \text { in year } t\end{cases}
$$

Individual characteristics are captured by $X$, which is a vector of socioeconomic variables: one gender dummy, 3 education dummies, and 15 dummies for the (SNI code) industry in which individual $i$ worked in year $t$. Further $X$ includes the individual's age in the form of a fourth-order polynomial: $A G E_{i t}, A G E_{i t}^{2}, A G E_{i t}^{3}$, and $A G E_{i t}^{4}$.

Finally, $R_{i t}$ is the reform indicator, defined as the interaction between the treatment indicator and the post-reform year dummies:

$$
R_{i t} \equiv T R E A T_{i t} \cdot \text { POSTREF }_{t},
$$

where POSTREF is a dummy taking the value of 1 for a post-reform year, and zero otherwise. With this definition, the interpretation of the coefficient $\beta$ in the regression equation (2) is the same as the $\beta$ in (1), when the averages $\bar{S}_{\text {contr,pre }}, \bar{S}_{\text {treat,post }}$ etc. are conditioned on all explanatory variables (YEAR, TREAT, $X$, and their interactions).

As pointed out in Section 2 above, it is not altogether obvious which years should be regarded as the post-reform period. While the reform was implemented in January 2001, the anticipation of the reform may, in principle, have influenced behavior already in 2000. We pointed out in connection with Table 3 that this may in fact have been the case. A reasonable baseline definition of POSTREF is therefore

$$
\operatorname{POSTREF}_{t}=Y_{t}^{00}+Y_{t}^{01}+Y_{t}^{02}
$$

As a sensitivity analysis, we will also try other alternatives (see below). 
Specification (2) includes interactions between each year-dummy and all elements of the $X$ vector, which prevents us from interpreting differential trends in the socioeconomic variables as reform effects. Our model includes around 100 separate variables, and it should be noted that we impose functional form restrictions only on the age variable; all other variables are dummies. The econometric identification of the model comes from variation within gender, sector, age and education groups, accounting for possible trends within these groups. The dependent variable is the number of days absent during a year (a limited dependent, count variable), and the OLS estimate of the coefficient $\beta$ measures the effect on this number of a policy change (see Angrist, 1999). In all regression models, standard errors are clustered by employer, to account for possible within firm correlation as well as individual autocorrelation (see Bertrand, Duflo and Mullainathan, 2004).

\subsection{The IV Specification}

There are several reasons why the assignment of workers to treatment and control group firms in our previous OLS analysis may be endogenous. Suppose, for example, that some workers have a relatively high propensity to be absent from work, reflecting heterogeneous preferences or some other unobservable characteristic. It is reasonable to assume that such workers prefer to work in firms with high job security. This implies that workers with such preferences or characteristics may move to firms not affected by the policy change. Conversely, workers in the control group who have low seniority, but have preferences or unobserved characteristics resulting in low work absence, may move to firms in the treatment group. The reason is that they would then not be harmed by their low seniority, but feel secure because of their strong work ethic.

We use an IV approach to deal with this endogeneity problem. In the OLS regression of Section 7.1, we used the variable TREAT, defined by (3), on the right-hand side of equation (2). Since this variable, or rather the reform assignment term $R_{i t} \equiv T R E A T_{i t} \cdot$ POSTREF $_{t}$, may be correlated with $e_{i t}$, we introduce the instrument

$$
Z_{i t} \equiv T R E A T_{i t} \cdot Y_{t}^{99}
$$


which means that

$$
Z_{i t}=\left\{\begin{array}{l}
1 \quad \text { if individual } i \text { works in a firm with } 2-10 \text { employees in } 1999 \\
0 \quad \text { otherwise. }
\end{array}\right.
$$

This instrument is exogenous since by 1999 , it was impossible for all but extremely clairvoyant workers to foresee the earlier-mentioned cooperation on this issue between the environmentalist Green party and the Conservative party. The instrument would, therefore, be unrelated to preferences for job security legislation. Moreover, the instrument is correlated with the reform assignment $R_{i t}$, since inertia in the employment relation means that most workers did not move from their original jobs as a result of the reform.

We thus estimate the following equation system:

$$
\begin{aligned}
R_{i t} & =a+b \cdot Z_{i t}+c_{Y E A R}^{\prime} \cdot Y E A R_{t}+c_{\text {TREAT }}^{\prime} \cdot \operatorname{TREAT}_{i t}+c_{X}^{\prime}{ }_{X} \cdot X_{i t}+ \\
& +c_{\text {INTERACT }}^{\prime} \cdot X_{i t} \cdot Y E A R_{t}+\varepsilon_{i t}, \\
S_{i t} & =\alpha+\beta \cdot R_{i t}+\gamma^{\prime}{ }_{Y E A R} \cdot Y E A R_{t}+\gamma_{\text {TREAT }}^{\prime} \cdot \text { TREAT }_{i t}+\gamma^{\prime}{ }_{X} \cdot X_{i t}+ \\
& +\gamma_{\text {INTERACT }}^{\prime} \cdot X_{i t} \cdot Y E A R_{t}+e_{i t},
\end{aligned}
$$

where $Z_{i t}$ is given by (7). The resulting parameter estimate $\hat{\beta}$ can be interpreted as the so-called local average treatment effect (LATE), i.e., the average effect of the reform for those who worked in a firm with 2-10 employees in 1999 and were exposed to a new job security regime as a result of the reform.

\section{Results}

\subsection{Results from the Differences-in-differences Model}

Estimating (2), using definitions (3) - (5) for the reform indicator, yields the estimates reported in Table 5. 
Table 5: Results from the differences-in-differences analysis of the effect of the 2001 reform. Unbalanced panel. Standard error in parenthesis.

\begin{tabular}{|c|c|c|c|c|c|c|}
\hline & \multirow{2}{*}{\multicolumn{2}{|c|}{$\begin{array}{c}\text { Entire sample } \\
\text { OLS } \\
\text { (A) }\end{array}$}} & \multicolumn{4}{|c|}{ Sample restricted to those in the population in 1999} \\
\hline & & & & S & & $\begin{array}{l}V \\
\text { C) }\end{array}$ \\
\hline & Pre: $1998-99$ & Pre: $1998-99$ & Pre: $1998-99$ & Pre: $1998-99$ & Pre: $1998-99$ & Pre: $1998-99$ \\
\hline & Post: $2000-02$ & Post: 2001-02 & Post: $2000-02$ & Post: $2001-02$ & Post: $2000-02$ & Post: 2001-02 \\
\hline $\begin{array}{l}\text { Reform effect, i.e., } \\
\text { the } \beta \text { estimate }\end{array}$ & $\begin{array}{l}-0.230 \\
(0.105)\end{array}$ & $\begin{array}{l}-0.267 \\
(0.070)\end{array}$ & $\begin{array}{l}-0.816 \\
(0.147)\end{array}$ & $\begin{array}{l}-0.945 \\
(0.157)\end{array}$ & \begin{tabular}{|l|}
-0.471 \\
$(0.299)$
\end{tabular} & $\begin{array}{l}-0.428 \\
(0.245)\end{array}$ \\
\hline $\begin{array}{l}\text { First-stage IV } \\
\text { regression (8): } \\
t \text {-value for } \\
b \text { estimate }\end{array}$ & - & - & & & 685.2 & 838.1 \\
\hline $\mathrm{R}^{2}$ & 0.016 & 0.017 & 0.016 & 0.018 & 0.016 & 0.018 \\
\hline $\begin{array}{l}\text { Number of } \\
\text { observations }\end{array}$ & $3,229,964$ & $2,574,487$ & $1,213,483$ & 970,657 & $1,213,483$ & 970,657 \\
\hline
\end{tabular}

Note: A quadratic polynomial in age, dummies for year, gender, four different education groups, 16 different sectors also included in the models and interactions between the age polynomial and the all indicators are also included in the specification. Correction for clustering on firm level across years are made in the estimation (see Moulton, 1996).

Table 5 contains three sets of results. For each of these sets, we have one specification including and one excluding the "ambiguous year" 2000. The first set of results (columns A) includes the entire population of workers working in firms with less than 25 employees for each of the years included in the sample. For the second two sets (columns B and C), we have restricted the sample to those who worked in firms included in the population in 1999. The reason for this restriction is that in order to use assignment to firms subsequently assigned to the reform as an instrumental variable, we need to know which type of firm they worked in1999. The second set of OLS results are included as a comparison to the IV results on the same population.

Let us first have a look at the OLS results on the entire population (columns A). These results refer to the definitions (3) - (5) for the reform indicator. The results show a (statistically) significant reform effect. From the first column, we see that the baseline model specification gives a point estimate of -0.230 days, i.e., because of the reform, each employee in the treatment group reduced absence by 0.230 days per year, on average. As a robustness check, we have also tried to define the pre-reform period as 
1998-1999 and the post-reform period as 2001-2002, i.e., we have disregarded the ambiguous year, 2000. The results are shown in the second column and we see that the $\beta$ estimate is -0.267 .

\subsection{Timing and Size Effects}

The model allows us to make two specific tests of the relations between the job security reform and sickness absence. One refers to the timing of the effects, the other to differential effects for firms of different size within the treatment group.

According to the results in Table 5, there is a significant difference between the preand the post-reform period, regardless of whether the post-reform period includes the year 2000 or not. To further clarify whether there was an effect already in 2000, we repeat the differences-in-differences approach for individual years, using 1998 as the benchmark. Therefore, we redefine the model as follows:

$$
R_{i t} \equiv\left[R_{i t}^{99}, R_{i t}^{00}, R_{i t}^{01}, R_{i t}^{02}\right]^{\prime} \equiv T R E A T_{i t} \cdot\left[Y_{t}^{99}, Y_{t}^{00}, Y_{t}^{01}, Y_{t}^{02}\right]^{\prime}
$$

The $\beta$ coefficient in the regression equation (2) should then be interpreted as a fourdimensional vector $\left(\beta^{99}, \beta^{00}, \beta^{01}, \beta^{02}\right)^{\prime}$ showing whether there is any difference-indifference not only for the year when the reform was implemented (i.e., 2001), but also for any of the years 1999, 2000 and 2002. Estimating (2) with this specification, we obtain the estimated parameter vector $\beta$ reported in Figure 3. 


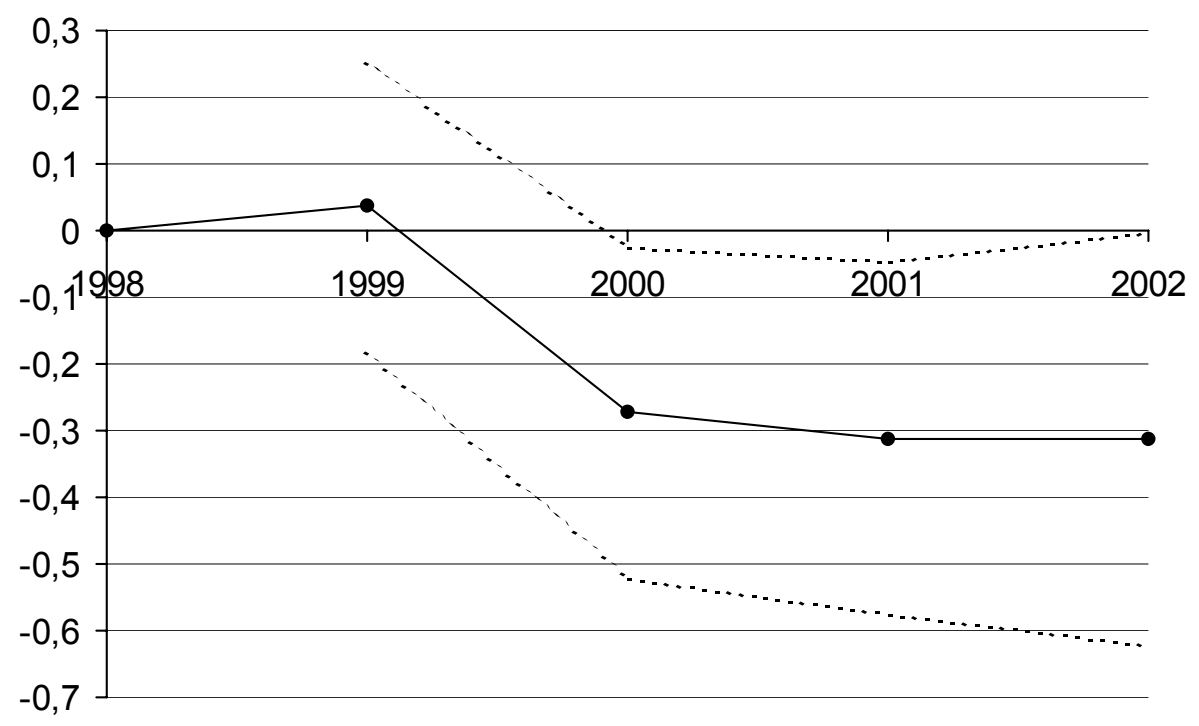

Figure 3: Point estimates of coefficients of the interaction coefficients $\beta^{99}, \beta^{00}, \beta^{01}, \beta^{02}$ in equation (2), using the definition (4'). $95 \%$ confidence intervals are indicated by the dashed curves.

Figure 3 shows that the estimate of $\beta^{99}$ is not significantly different from zero (with 1998 as the base year). In 2000, however, something happens; the coefficient falls sharply, and remains at around -0.3 for each of the years 2000, 2001 and 2002. This result indicates that it is reasonable to regard the three years $2000-2002$ as the postreform period - a view reflected already in the raw data of Table 3.

Repeating the analysis, following Donald and Lang (2004), from Section 5.1, we find that the difference between $\hat{\beta}^{99}$ on one hand, and $\hat{\beta}^{00}, \hat{\beta}^{01}$ and $\hat{\beta}^{02}$ on the other is significant. Regressing the differences shown in Figure 3 on a dummy variable taking the value one for 2000, 2001 and 2002, we obtain a significant coefficient estimate equal to 0.21 (with a standard error of 0.042 and a $p$ value of 1.6 percent). The point estimate for the dummy variable, in the analysis under less restrictive assumptions when regressing the one-year differences-indifferences on a dummy variable for the year 2000 , is 0.30 and the standard error is 0.048 . These estimates give a $p$ value of 2.4 percent in a test of statistical significance. 
As pointed out in Section 4, our hypothesis about effects on sickness absence of the 2001 Swedish reform has testable implications also for firms of different size within the treatment group. The general pattern of the predicted effects is illustrated by the U-shaped curve in Figure 1. To test this hypothesis, we reformulate the regression equation (2):

$$
\begin{aligned}
S_{i t}= & \alpha+\beta^{\prime} \cdot R_{i t}+\gamma_{Y E A R}^{\prime} \cdot Y E A R_{t}+\gamma_{S I Z E}^{\prime} \cdot S I Z E_{i t}+\gamma_{X}^{\prime} \cdot X_{i t}+ \\
& +\gamma_{\text {interact }}^{\prime} \cdot X_{i t} \cdot Y E A R_{t}+e_{i t},
\end{aligned}
$$

where the TREAT variable in equation (2) is simply replaced by the SIZE variable, a vector of dummy variables for each firm size between 1 and 19 employees.

We now capture the reform by the interaction between the SIZE variable and the postreform period dummy POSTREF:

$$
R_{i t} \equiv S I Z E_{i t} \cdot \operatorname{POSTREF}_{t},
$$

with POSTREF defined by (5). While in Section 7.2 we studied how the reform acted during each of the six years (having only two size classes), we can now study how the reform acted on each of 19 size classes. We thus obtain the reform coefficient $\beta$ as a 19-dimensional vector, with one element for each size class. ${ }^{7}$ The estimated elements $\beta^{1}, \beta^{2}, \ldots, \beta^{19}$ are reported in Figure 4.

\footnotetext{
${ }^{7}$ The reason why we only estimated 19 coefficients $\gamma$, grouping all firms with 20-25 employees into the "default" group (instead of estimating 24 coefficients, using firms with 25 employees as the default), is that we wanted the default group to contain a sufficiently large number of observations. Using only one size class (e.g., firms with exactly 25 employees, or exactly 24 employees) makes the estimates of $\gamma$ quite unstable.
} 


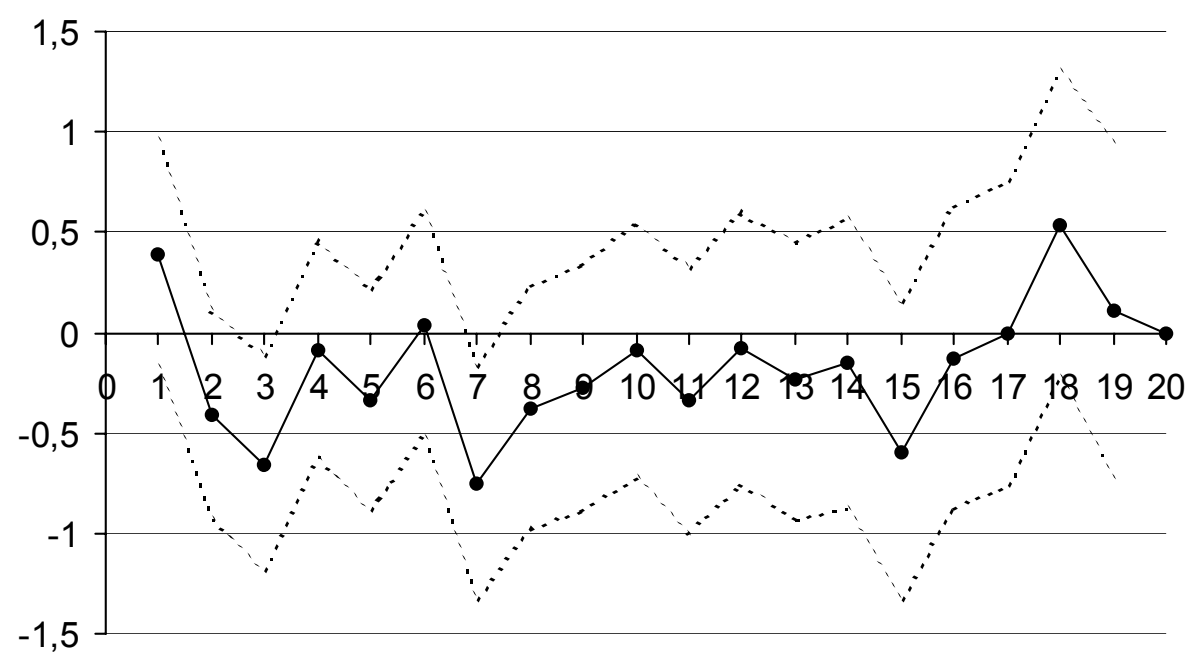

Size

Figure 4: Point estimates of coefficients of the interaction coefficients $\beta^{1}, \beta^{2}, \ldots, \beta^{19}$ in equation (4'). Size class 20 is the reference alternative $\left(\beta^{20}, \ldots ., \beta^{25} \equiv 0\right)$. Dashed curves indicate $95 \%$ confidence intervals.

We see that the size profile of the reform effect, reflecting the $\beta$ estimates, in Figure 4 has a general pattern that is somewhat similar to the predicted size profile in Figure 1. The estimated effects are, however, in general not significant, which probably reflects a large amount of noise in the data. ${ }^{8}$ It is, nevertheless, noteworthy that the size for which the predicted effects are the largest, namely firms with three employees, for which the reform abolished the seniority rules completely, shows a significant reform effect of -0.65 days. The general shape of the estimated $\beta$ vector, therefore, does not contradict the theoretical predictions of how the reform should affect firms within the treatment group.

\subsection{Endogeneity of Reform Assignment}

As we explain in Section 6, there are several reasons why observed assignment to the reform may be endogenous. To account for this possibility, and to decompose the overall effect presented in the first set of results in Table 5 into a behavioral and a compositional effect, we use an instrumental variable technique. As mentioned 
earlier, we construct the instrumental variable by assigning the individual to the firm where he worked in 1999, before it was at all possible to know about the changes in the job security legislation.

The second and third sets of results in Table 5 (columns B and C) show the outcome of this exercise, i.e., the IV results along with the OLS ones obtained on the same population for the sake of comparison. The OLS estimates of the reform effect shown here are larger than the corresponding ones obtained on the entire population. The reason for this is that the population differs between the two sets of estimates: the workers included in the experimental in the balanced panel are likely to have longer seniority, since they worked both before and after the reform. They may, therefore, be more strongly affected by the reform than the entire population since, on average, they lose more seniority capital. ${ }^{9}$

Columns $\mathrm{C}$ in Table 5 reports the $t$ value from the excluded instrument from the first step in the 2SLS estimation procedure. Since these $t$ values are exceptionally large, we can conclude that we use very strong instruments. Another issue is whether we can conclude from these estimates that compositional changes affect the estimated effect of the reform, i.e., whether the variable for reform assignment can be treated as exogenous. For this reason, we compare the OLS estimates of the reform effect $(\beta)$ in column B to the IV estimates of the reform effect in column C. For the sample when the year 2000 is excluded, the difference between the OLS and IV estimates of $\beta$ is significant on the five percent level. For this sample, exogeneity of reform assignment can thus be rejected in a so-called Hausman test.

The $\beta$ estimates are at least marginally different from zero ( $p$ values are 0.116 when the year 2000 is included, and 0.081 when it is not). This means that we may, although with a low level of significance, still argue that the reform did have an effect on the behavior of the workers who were exposed to a new job security regime as a

\footnotetext{
${ }^{8}$ For instance, a firm that had 5 employees when our data was reported may very well have 4 or 6 employees at the point in time when there is need for a reduction of the workforce.

${ }^{9}$ The treatment of the age variable also differs; in Table 5, we used 39 age dummies, but for the IV estimates we had to reduce the dimensionality of the problem by instead using a quadratic polynomial in age. For the sake of comparability, we also used that polynomial for the OLS estimates reported in Table 6.
} 
result of the reform. As for the size of the behavioral effect as compared to the compositional effect, we note that the point estimates of $\beta$ in the IV specification are about half the size of the point estimates in the OLS specification. This means, roughly speaking, that the behavioral effect is about half the size of the overall effect.

The panel character of our data allows us to further analyze the compositional changes. The difference between the IV and OLS estimates in Table 5 is generated by the behavioral differences between the groups that leave and enter the firms affected by the reform. Table 6 shows how these groups are defined. The columns refer to the type of firm in which the worker was employed before the reform (in 1999) and the rows the type after the reform. The OLS estimates mean that we compare workers who are employed in firms with 2-10 employees after the reform (i. e., workers in cells 3 and 4 in the table) to workers who are not employed in such firms (i. e., workers in cells 1 and 2). Similarly, the IV estimates compare workers who were employed in firms with 2-10 employees before the reform (i. e., workers in cells 2 and 4) to workers who were not employed in such firms (i. e., workers in cells 1 and 3).

Table 6. Definition of groups of workers included in the OLS and IV estimates of the effect of the reform.

\begin{tabular}{|l|c|c|}
\hline & $\begin{array}{l}\text { Work pre-reform (in 1999) in } \\
\text { firms included in the control } \\
\text { group (1 or 11-25 employees) }\end{array}$ & $\begin{array}{l}\text { Work pre-reform (in 1999) in } \\
\text { firms subsequently affected by } \\
\text { the reform (2-10 employees) }\end{array}$ \\
\hline $\begin{array}{l}\text { Work post-reform in firm not } \\
\text { affected by the reform (1 or 11- } \\
25 \text { employees) }\end{array}$ & $\mathbf{1}$ & \\
\hline $\begin{array}{l}\text { Work post-reform in firm } \\
\text { affected by the reform (2-10 } \\
\text { employees) }\end{array}$ & $\mathbf{3}$ & $\mathbf{4}$ \\
\hline
\end{tabular}

In the discussion at the beginning of this section, we concluded that the group of workers leaving firms affected by the reform may have preferences for a stricter job security legislation, because they have preferences for being absent from work. The group of workers moving to firms affected by the reform may, similarly, have preferences for weaker job security legislation, since they believe that they may 
benefit from working in a firm that puts less weight on seniority and more weight on work ethic.

Although it is not possible to observe the counterfactual outcome of the work absence behavior of workers in their original job security regime, it is still possible to compare their behavior vis-à-vis the workers originally in the two groups, respectively. This is done by simply splitting up the OLS and IV reform indicators, according to the definitions in Table 6. This implies that we estimate the following two models:

$$
S_{i t}=\alpha+\beta_{3} \cdot R_{i t}^{\text {Group } 3}+\beta_{4} \cdot R_{i t}^{\text {Group } 4}+\gamma_{Y E A R}^{\prime} T_{R E A T}+\gamma^{\prime}{ }_{X} X_{i t}+e_{i t}
$$

and

$$
S_{i t}=\alpha+\beta_{2} \cdot R_{i t}^{\text {Group } 2}+\beta_{4} \cdot R_{i t}^{\text {Group } 4}+\gamma_{Y E A R}^{\prime} \operatorname{TREAT}_{i t}+\gamma^{\prime}{ }_{X} X_{i t}+e_{i t} .
$$

In the OLS estimations reported in Table 5, we estimated equation (10) but did not distinguish between $\beta_{3}$ and $\beta_{4}$. Similarly, if we had estimated the reduced form ${ }^{10}$ of the IV specification (8)-(9), we would have estimated equation (11) without distinguishing between $\beta_{2}$ and $\beta_{4}$. By the OLS estimates of (10) and (11), we can distinguish between these different $\beta$ values, which give us a richer picture of the flows between the treatment group and the control group.

\footnotetext{
${ }^{10}$ Estimating the reduced form means estimating (9) by OLS, but using the $Z_{i t}$ given by definition (7) instead of the (simultaneously estimated) $R_{i t}$ given by (8). By using the reduced form, rather than the IV model itself, we circumvent the problem of finding an additional instrument.
} 
Table 7: Decomposition of the OLS and the reduced form for the IV estimates of the effects of the reform on work absence. Standard errors within parentheses.

\begin{tabular}{|c|c|c|c|c|}
\hline & \multicolumn{2}{|c|}{$\begin{array}{l}\text { Decomposition of } \\
\text { OLS estimate }\end{array}$} & \multicolumn{2}{|c|}{$\begin{array}{l}\text { Decomposition of } \\
\text { IV estimate }\end{array}$} \\
\hline & Pre: $1998-99$ & Pre: 1998-99 & Pre: 1998-99 & Pre: 1998-99 \\
\hline & Post: $2000-02$ & Post: 2001-02 & Post: $2000-02$ & Post: 2001-02 \\
\hline $\begin{array}{l}\text { Stay in reform } \\
\text { firms ( } \beta_{4} \\
\text { estimate) }\end{array}$ & $\begin{array}{l}-0.820 \\
(0.127)\end{array}$ & $\begin{array}{l}-1.028 \\
(0.160)\end{array}$ & $\begin{array}{l}-0.643 \\
(0.131)\end{array}$ & $\begin{array}{l}-0.769 \\
(0.162)\end{array}$ \\
\hline $\begin{array}{l}\text { Move to firms } \\
\text { affected by the } \\
\text { reform ( } \beta_{3} \\
\text { estimate) }\end{array}$ & $\begin{array}{l}-0.209 \\
(0.242)\end{array}$ & $\begin{array}{l}-0.359 \\
(0.288)\end{array}$ & - & - \\
\hline $\begin{array}{l}\text { Move out from } \\
\text { firms affected } \\
\text { by the reform } \\
\text { ( } \beta_{2} \text { estimate) }\end{array}$ & - & - & $\begin{array}{c}0.778 \\
(0.231)\end{array}$ & $\begin{array}{c}0.905 \\
(0.277)\end{array}$ \\
\hline $\mathrm{R}^{2}$ & 0.016 & 0.018 & 0.016 & 0.018 \\
\hline $\begin{array}{l}\text { Number of } \\
\text { observations }\end{array}$ & $1,213,483$ & 970,657 & $1,213,483$ & 970,657 \\
\hline
\end{tabular}

Note: A quadratic polynomial in age, dummies for year, gender, four different education groups, 16 different sectors also included in the models. Stayers in firms not affected by the reform (1) correspond to 31.8 percent of the sample; movers from firms subsequently affected by the reform to firms not affected (2) 8.3 percent; movers from firms subsequently not affected by the reform to firms affected (3) 6.6 percent; stayers in firms affected by the reform 53.3 percent. Correction for clustering at the firm level made in the estimation (see Moulton, 1996).

Table 7 presents the results from this extended analysis. The specifications presented in the first two columns decompose the OLS estimates. The specifications presented in the next two columns do the same for the reduced form of the IV model. The results, in all specifications, show that those who remain in the category of firms affected by the reform significantly decreased their work absence - in the first two models relative to the groups defined by squares 1 and 2 in Table 6 and in the last two models relative to the groups defined by squares 1 and 3 . The results from the first two models show that those who move to the firms affected by the reform on average have a significantly higher work absence rate than those who remain in this category of firms. Finally, the results from the last two models show that those who change employers from one in the treatment group to one in the control group on average 
have a significantly higher work absence rate than the workers remaining in this kind of firm.

This extended analysis gives us further insight into the sources of endogeneity in the original model. First, those who move from firms affected by the reform have a significantly higher work absence than those remaining in those firms (i. e., $\hat{\beta}_{2}>\hat{\beta}_{4}$ ). This suggests either that those with preferences for the weaker job security legislation are also more absent from work, or that the control-group employers can take advantage of the weaker job security legislation to get rid of sick workers. This effect is consistent with lower firing costs for the firms directly affected by the reform and an obvious source of endogeneity, since it reinforces the OLS estimate of the reform. Second, those who enter the firms directly affected by the reform after the policy change on average have higher work absence than those remaining in these firms (i. e., $\hat{\beta}_{3}>\hat{\beta}_{4}$ ). This factor attenuates the OLS estimates of the effect of the reform. Note also that this effect is consistent with the incentives of lower hiring costs after the reform; the employers scrutinize less and hence, dare employ new people with potentially worse health than the old employees.

To sum up, three main conclusions emerged from this sub-section. First, exogeneity of the reform on work absence behavior may be rejected. This conclusion partly emerged from the significant outcome from the Hausman test on the difference between the OLS and IV estimates when the year 2000 was excluded from the analysis. It was confirmed by the result in the extended analysis suggesting that those who move from firms affected by the reform on average have a higher work absence than other workers in the control group after the reform. Second, there is a behavioral effect of the reform also when accounting for endogeneity of the reform. Although this result is not quite significant when including the year 2000 in the analysis, it is significant at the ten-percent level when excluding this year. Third, the source of endogeneity is that workers move out of firms affected by the reform. This compositional change reinforces the effect of the reform, while those who move to the firms affected by the reform attenuate the effect. 


\subsection{A Panel-Data Approach}

There is also another way of studying the flows into, and out of, the treatment group. From our original data, we construct consecutive two-year panels, which enables us to explicitly compare the work absence behavior of workers who change employers, before and after the reform of the job security legislation. By this approach, we can identify not only entrants, but also leavers.

Let us start with entrants, i.e., the hiring decision. Do our individual panel data support our result that the reform encouraged firms to hire people with a relatively high absence record? More specifically, did the willingness of firms in the treatment group to hire such individuals increase more than that of firms in the control group? To study this question, we look at individuals who change employers between two years. Therefore, we estimate the following regression equation for a number of twoyear panels:

$$
s_{i 1}=\alpha+\gamma b_{i}+\eta b_{i} r_{i 2}+\varepsilon_{i 1} .
$$

Here, $s_{i 1}$ is the number of days of absence for individual $i$ in the first year of our twoyear panel, while $b_{i}$ is a dummy variable equal to one if the individual begins a new job with a new employer in the second year, and zero otherwise. Finally, $r_{i 2}$ is a dummy variable that equals one if the individual works in a treatment-group firm in the second year.

Thus formulated, coefficient $\gamma$ tells us whether those who moved to a new firm between the two years used to have a higher $(\gamma>0)$ or a lower $(\gamma<0)$ absence at their old jobs than those who did not move. Similarly, $\eta$ tells us whether those who moved to a treatment-group firm (the "entrants") used to have a higher $(\eta>0)$ or a lower $(\eta<0)$ absence at their old job than the other movers. If treatment-group firms became more willing to employ persons with a bad health record, we would expect $\eta>0$ for the years after the reform. 
It is not, however, only the employee's absence behavior before getting a new job that is interesting in the present context. To study the behavior after getting a new job, we reformulate (6) slightly:

$$
s_{i 2}=\alpha+\gamma b_{i}+\eta b_{i} r_{i 2}+\varepsilon_{i 2} .
$$

Note that the dependent variable is now $s_{i 2}$, the number of days absent during the second year of our two-year panel. Now, parameter $\eta$ tells us whether entrants to treatment-group firms tend to have a higher or a lower absence than other movers at their new job. Also in this case would an estimate $\eta>0$ after the reform give support to the view that the reform made treatment-group firms more prone to employ persons with potential health problems.

In equations (6) and (6'), we have studied entrants to treatment-group firms. We will also study leavers from treatment-group firms. For this purpose, we write the regression equation as

$$
s_{i 1}=\alpha+\gamma b_{i}+\eta b_{i} r_{i 1}+\varepsilon_{i 1} .
$$

Here, $r_{i 1}$ is a dummy variable taking the value of one if the individual works in a treatment-group firm during the first year of our two-year panel. A positive value of $\eta$ would then indicate that those who leave treatment-group firms had a higher absence at their old jobs than other movers.

Finally, we write the regression equation as

$$
s_{i 2}=\alpha+\gamma b_{i}+\eta b_{i} r_{i 1}+\varepsilon_{i 1}
$$

A positive $\eta$ would now tell us that those who leave treatment-group firms have a higher absence at their new job than other movers, also lending support to the view that treatment-group firms get rid of people with health problems. A negative $\eta$ 
would, on the other hand, lend some support to the view that an individual who leaves a treatment-group firm also leaves a bad match.

Table 8 shows the results from the four regression equations above, based on data from six different two-year panels covering the period 1998/99 to 2001/02. First, almost all coefficients are positive and statistically significant. This means that individuals entering and individuals leaving treatment-group firms have a higher sickness absence than those entering and leaving control-group firms. This applies to all years, before as well as after the reform.

This difference increased significantly after the reform, i.e. by about 1.5 days according to columns 1 and 2. In other words, firms became more inclined to hire individuals with a relatively high absence both at their old job (column 1) and at their new job (column 2). According to column 3, individuals with a high absence record also tended to leave control-group firms after the reform (due to quits and/or firing).

It is worth noting that the effects on entrants did not emerge until one year after the reform, while in the case of leavers, it occurred in the reform year 2001. In other words, the effects on firing and/or quitting emerged before the effects on hiring. ${ }^{11}$ As we saw earlier (Figure 3), the net effect, including both behavioral and compositional effects, occurred already in the year 2000. Therefore, the net fall in absence in 2000 was the result of the behavioral effect only. 
Table 8. Differences in average number of days on work absence between entrants and leavers in the experimental group compared to entrants and leavers in the control group before and after entry and exit, respectively. Standard errors adjusted for clustering within firms in parentheses.

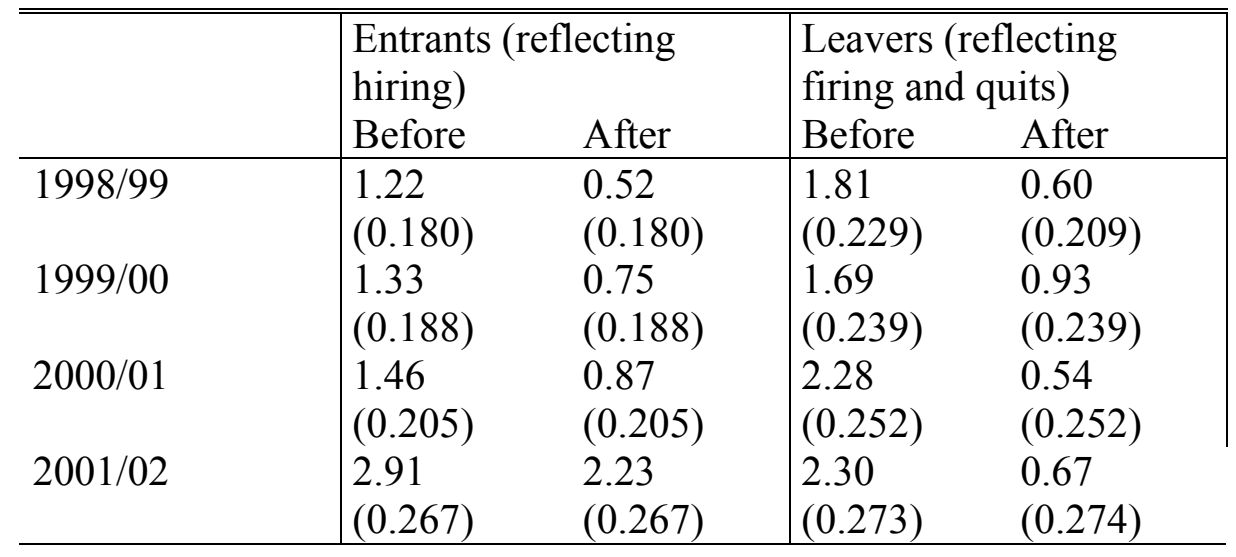

To sum up, the results obtained in this sub-section reinforce those obtained in Subsection 7.2. The results from the panel study show that persons with a high propensity to call sick tend to leave the treatment firms, which by itself tends to reduce sickness absence in those firms. On the other hand, treatment firms become less reluctant to hire individuals with potential health problems, which tends to drive up absence in such firms. Both these effects are in conformity with the predicted effects in Section 2.

\section{Conclusions}

In this paper, we have exploited a natural experiment to investigate whether job security legislation influences sickness absenteeism. The empirical results suggest that the softening of the last-in-first-out rules for small firms in Sweden in 2001 reduced sickness absence by around 0.25 days per year per employee, or by about 3.3 percent, in the group of firms affected by the change in the legislation. One should, however, also notice that for the firms that were expected to be most affected by the reform (i.e., firms with 2-3 employees, who lost all their seniority capital), absence fell by 0.4-0.65 days, according to the estimates reported in Figure 4. Moreover, for those

\footnotetext{
${ }^{11}$ There were no significant differences, however, between those who left treatment-group firms and those who left control-group firms, in terms of absence at their new job (column 4).
} 
who stayed in treatment firms after the reform ("stayers") the absence fell by approximately one day.

These effects may seem small, but it should be remembered that the policy experiment was very modest. It did not imply a removal of job security legislation for small firms; it only meant that such firms could exempt two persons from the seniority rules in case of redundancy. Stronger effects would be expected with a more far-reaching reform of the job security legislation.

Moreover, our estimates probably only give a lower bound for the effects, since available data only cover spells of sickness absence longer than 14 days. There are reasons to assume that job security legislation also influences shorter spells; indeed, moral hazard problems in connection with job security may very well be more important for short than for long spells.

We have pointed out that the reform may affect absence in the treatment-group firms in four ways: the firms may find it easier to fire workers with a high absence, some workers may prefer to leave the treatment-group firms voluntarily, the firms may be more inclined to hire workers with a high absence, and workers in the treatment-group firms may reduce their absence. The first two effects cannot be separated in our data, since it is impossible to say whether a worker who has left a treatment-group firm has done that voluntarily or involuntarily. Therefore, we have three discernable effects: one via firing and/or quits, one via hiring, and one behavioral effect. Our data indicate that all three effects are present; the behavioral effect being the quantitatively most important one (amounting to roughly half of the total effect).

From a budgetary point of view of the insurance system, the total effect of about 0.25 days is the most relevant aspect of the reform. From a welfare point of view, each different component of the net compositional effect is also important since the welfare effects differ for firing, quits, and hiring. When looking at firing, it is instructive to regard job security legislation as a kind of insurance against the risk of losing one's job. The reform redistributed the protection against this risk from individuals with more health problems to individuals with less such problems. Some persons lost their 
seniority capital - but since seniority is a zero-sum game, others thus got a higher probability of keeping their jobs.

People who decided to quit after the reform also made a welfare loss by the reduction of their seniority capital, but this loss was counteracted by getting a better job match in another firm. For society as a whole, this meant a welfare gain in the form of a more efficient allocation of labor across firms. The most clear-cut welfare gain for individuals was, however, that those with a poor health record got a better chance of being hired. Since this group, at least to some extent, consists of "outsiders", living on unemployment benefits and other transfers, their increased chance of getting a job may constitute a considerable welfare gain to society. 


\section{References}

Angrist, J. (1999) "Estimation of Limited-Dependent Variable Models with Binary Endogenous Regressors: Simple Strategies for Empirical Practice", Journal of Business and Economic Statistics 19, 2-16.

Angrist, J. D. and A. B. Krueger (1999) "Empirical Strategies in Labor Economics". In O. Ashenfelter and D. Card (eds) Handbook of Labor Economics vol 3A. Amsterdam: North-Holland.

Bertrand, M., E. Duflo and S. Mullainathan (2004) "How Much Should We Trust Difference in Difference Estimates", Quarterly Journal of Economics, 119 (1), 249275.

Donald, S. and K. Lang (2004) "Inference with Difference in Differences and Other Panel Data". Mimeo, Boston University.

Osborg Ose, S. \& J. M. Dyrstad (2001), "Non-linear Unemployment Effects in Sickness Absence: Discipline or Composition Effects?", WP 2502, Department of Economics, Norwegian University of Science and Technology.

Henrekson, M. och M. Persson (2004), "The Effects on Sick Leave of Changes in the Sickness Insurance System”, Journal of Labour Economics, 22(1), s. 87--113.

Ichino, A. and Maggi, G. (2000) "Work Environment and Individual Background: Explaining Regional Shirking Differentials in a Large Italian Firm", Quarterly Journal of Economics 115(3), 1057-1090.

Ichino, A. and R. Riphahn (2005) "The Effect of Employment Protection on Worker Effort - A Comparison of Absenteeism During and After Probation", Journal of the European Economic Association 3(1) 120-143.

Johansson, P. and M. Palme (2005) "Moral Hazard and Sickness Insurance". Journal of Public Economics, 89(9-10), 1879-1890.

Malcomson, J. M. (1999) “Individual Employment Contracts". In O. Aschenfelter and D. Card (eds.) Handbook of Labor Economics, vol 3B. Amsterdam: North-Holland.

Moulton, B. (1986) "Random Group Effects and the Precision of Regression Estimates". Journal of Econometrics 32(3), 385-397.

Riphahn, R. and A. Ichino (2004) "Absenteeism and Employment Protection: Three Case Studies", Swedish Economic Policy Review 11, 96-119.

Rothstein, B. and F. Boräng (2005), "Dags att dra in guldklockorna? Om rörlighet och sjukfrånvaro på den svenska arbetsmarknaden", mimeo, Department of Political Science, Gothenburg University. 


\section{CESifo Working Paper Series}

(for full list see www.cesifo-group.de)

1625 Sam Bucovetsky and Andreas Haufler, Tax Competition when Firms Choose their Organizational Form: Should Tax Loopholes for Multinationals be Closed?, December 2005

1626 Silke Uebelmesser, To go or not to go: Emigration from Germany, December 2005

1627 Geir Haakon Bjertnæs, Income Taxation, Tuition Subsidies, and Choice of Occupation: Implications for Production Efficiency, December 2005

1628 Justina A. V. Fischer, Do Institutions of Direct Democracy Tame the Leviathan? Swiss Evidence on the Structure of Expenditure for Public Education, December 2005

1629 Torberg Falch and Bjarne Strøm, Wage Bargaining and Political Strength in the Public Sector, December 2005

1630 Hartmut Egger, Peter Egger, Josef Falkinger and Volker Grossmann, International Capital Market Integration, Educational Choice and Economic Growth, December 2005

1631 Alexander Haupt, The Evolution of Public Spending on Higher Education in a Democracy, December 2005

1632 Alessandro Cigno, The Political Economy of Intergenerational Cooperation, December 2005

1633 Michiel Evers, Ruud A. de Mooij and Daniel J. van Vuuren, What Explains the Variation in Estimates of Labour Supply Elasticities?, December 2005

1634 Matthias Wrede, Health Values, Preference Inconsistency, and Insurance Demand, December 2005

1635 Hans Jarle Kind, Marko Koethenbuerger and Guttorm Schjelderup, Do Consumers Buy Less of a Taxed Good?, December 2005

1636 Michael McBride and Stergios Skaperdas, Explaining Conflict in Low-Income Countries: Incomplete Contracting in the Shadow of the Future, December 2005

1637 Alfons J. Weichenrieder and Oliver Busch, Artificial Time Inconsistency as a Remedy for the Race to the Bottom, December 2005

1638 Aleksander Berentsen and Christopher Waller, Optimal Stabilization Policy with Flexible Prices, December 2005

1639 Panu Poutvaara and Mikael Priks, Violent Groups and Police Tactics: Should Tear Gas Make Crime Preventers Cry?, December 2005 
1640 Yin-Wong Cheung and Kon S. Lai, A Reappraisal of the Border Effect on Relative Price Volatility, January 2006

1641 Stefan Bach, Giacomo Corneo and Viktor Steiner, Top Incomes and Top Taxes in Germany, January 2006

1642 Johann K. Brunner and Susanne Pech, Optimum Taxation of Life Annuities, January 2006

1643 Naércio Aquino Menezes Filho, Marc-Andreas Muendler and Garey Ramey, The Structure of Worker Compensation in Brazil, with a Comparison to France and the United States, January 2006

1644 Konstantinos Angelopoulos, Apostolis Philippopoulos and Vanghelis Vassilatos, RentSeeking Competition from State Coffers: A Calibrated DSGE Model of the Euro Area, January 2006

1645 Burkhard Heer and Bernd Suessmuth, The Savings-Inflation Puzzle, January 2006

1646 J. Stephen Ferris, Soo-Bin Park and Stanley L. Winer, Political Competition and Convergence to Fundamentals: With Application to the Political Business Cycle and the Size of Government, January 2006

$1647 \mathrm{Yu}-\mathrm{Fu}$ Chen, Michael Funke and Kadri Männasoo, Extracting Leading Indicators of Bank Fragility from Market Prices - Estonia Focus, January 2006

1648 Panu Poutvaara, On Human Capital Formation with Exit Options: Comment and New Results, January 2006

1649 Anders Forslund, Nils Gottfries and Andreas Westermark, Real and Nominal Wage Adjustment in Open Economies, January 2006

1650 M. Hashem Pesaran, Davide Pettenuzzo and Allan G. Timmermann, Learning, Structural Instability and Present Value Calculations, January 2006

1651 Markku Lanne and Helmut Luetkepohl, Structural Vector Autoregressions with Nonnormal Residuals, January 2006

1652 Helge Berger, Jakob de Haan and Jan-Egbert Sturm, Does Money Matter in the ECB Strategy? New Evidence Based on ECB Communication, January 2006

1653 Axel Dreher and Friedrich Schneider, Corruption and the Shadow Economy: An Empirical Analysis, January 2006

1654 Stefan Brandauer and Florian Englmaier, A Model of Strategic Delegation in Contests between Groups, January 2006

1655 Jan Zápal and Ondřej Schneider, What are their Words Worth? Political Plans and Economic Pains of Fiscal Consolidations in New EU Member States, January 2006 
1656 Thiess Buettner, Sebastian Hauptmeier and Robert Schwager, Efficient Revenue Sharing and Upper Level Governments: Theory and Application to Germany, January 2006

1657 Daniel Haile, Abdolkarim Sadrieh and Harrie A. A. Verbon, Cross-Racial Envy and Underinvestment in South Africa, February 2006

1658 Frode Meland and Odd Rune Straume, Outsourcing in Contests, February 2006

1659 M. Hashem Pesaran and Ron Smith, Macroeconometric Modelling with a Global Perspective, February 2006

1660 Alexander F. Wagner and Friedrich Schneider, Satisfaction with Democracy and the Environment in Western Europe - a Panel Analysis, February 2006

1661 Ben J. Heijdra and Jenny E. Ligthart, Fiscal Policy, Monopolistic Competition, and Finite Lives, February 2006

1662 Ludger Woessmann, Public-Private Partnership and Schooling Outcomes across Countries, February 2006

1663 Topi Miettinen and Panu Poutvaara, Political Parties and Network Formation, February 2006

1664 Alessandro Cigno and Annalisa Luporini, Optimal Policy Towards Families with Different Amounts of Social Capital, in the Presence of Asymmetric Information and Stochastic Fertility, February 2006

1665 Samuel Muehlemann and Stefan C. Wolter, Regional Effects on Employer Provided Training: Evidence from Apprenticeship Training in Switzerland, February 2006

1666 Laszlo Goerke, Bureaucratic Corruption and Profit Tax Evasion, February 2006

1667 Ivo J. M. Arnold and Jan J. G. Lemmen, Inflation Expectations and Inflation Uncertainty in the Eurozone: Evidence from Survey Data, February 2006

1668 Hans Gersbach and Hans Haller, Voice and Bargaining Power, February 2006

1669 Françoise Forges and Frédéric Koessler, Long Persuasion Games, February 2006

1670 Florian Englmaier and Markus Reisinger, Information, Coordination, and the Industrialization of Countries, February 2006

1671 Hendrik Hakenes and Andreas Irmen, Something out of Nothing? Neoclassical Growth and the 'Trivial' Steady State, February 2006

1672 Torsten Persson and Guido Tabellini, Democracy and Development: The Devil in the Details, February 2006 
1673 Michael Rauber and Heinrich W. Ursprung, Evaluation of Researchers: A Life Cycle Analysis of German Academic Economists, February 2006

1674 Ernesto Reuben and Frans van Winden, Reciprocity and Emotions when Reciprocators Know each other, February 2006

1675 Assar Lindbeck and Mats Persson, A Model of Income Insurance and Social Norms, February 2006

1676 Horst Raff, Michael Ryan and Frank Staehler, Asset Ownership and Foreign-Market Entry, February 2006

1677 Miguel Portela, Rob Alessie and Coen Teulings, Measurement Error in Education and Growth Regressions, February 2006

1678 Andreas Haufler, Alexander Klemm and Guttorm Schjelderup, Globalisation and the Mix of Wage and Profit Taxes, February 2006

1679 Kurt R. Brekke and Lars Sørgard, Public versus Private Health Care in a National Health Service, March 2006

1680 Dominik Grafenhofer, Christian Jaag, Christian Keuschnigg and Mirela Keuschnigg, Probabilistic Aging, March 2006

1681 Wladimir Raymond, Pierre Mohnen, Franz Palm and Sybrand Schim van der Loeff, Persistence of Innovation in Dutch Manufacturing: Is it Spurious?, March 2006

1682 Andrea Colciago, V. Anton Muscatelli, Tiziano Ropele and Patrizio Tirelli, The Role of Fiscal Policy in a Monetary Union: Are National Automatic Stabilizers Effective?, March 2006

1683 Mario Jametti and Thomas von Ungern-Sternberg, Risk Selection in Natural Disaster Insurance - the Case of France, March 2006

1684 Ken Sennewald and Klaus Waelde, "Itô's Lemma" and the Bellman Equation for Poisson Processes: An Applied View, March 2006

1685 Ernesto Reuben and Frans van Winden, Negative Reciprocity and the Interaction of Emotions and Fairness Norms, March 2006

1686 Françoise Forges, the Ex Ante Incentive Compatible Core in Exchange Economies with and without Indivisibilities, March 2006

1687 Assar Lindbeck, Mårten Palme and Mats Persson, Job Security and Work Absence: Evidence from a Natural Experiment, March 2006 